\title{
Gustav Heinrich Kirchenpauer (1808-1887) of the City of Hamburg, and his research on hydroids and bryozoans
}

\author{
DALE R. CALDER ${ }^{1} \&$ ANITA BRINCKMANN-VOSS \\ Department of Natural History, Royal Ontario Museum, 100 Queen's Park, Toronto, Ontario, Canada M5S 2C6 \\ ${ }^{1}$ Corresponding author.E-mail: dalec@rom.on.ca
}

\begin{abstract}
Gustav Heinrich Kirchenpauer was born 2 February 1808 in Hamburg, and he died in that city on 3 March 1887 . In 1810 he was taken with his family to St. Petersburg, Russia, to escape economic hardships during the occupation of Hamburg and continental blockade of the United Kingdom by Napoleon. He attended secondary school and university in Dorpat (Tartu), Estonia, and earned a doctorate in law from Universtät Heidelberg in 1831. Kirchenpauer returned to Hamburg in 1832 as a lawyer and journalist, gaining recognition as a specialist in international trade. He later served as senator, federal council representative, and seven-time Bürgermeister (mayor) of the city. One of his avocations was natural history, especially taxonomy of hydroids and bryozoans. While he published only six papers with information on Hydrozoa, Kirchenpauer described and named eight genera and 77 species and subspecies of hydroids. Three familiar genera (Abietinaria, Lytocarpia, Macrorhynchia) and nearly half of the species he founded are still recognized as valid. In four papers dealing at least in part with Bryozoa, he named and described one new genus and 26 new species-group taxa in that group. Hydroids and bryozoans studied and described by Kirchenpauer came from many parts of the world, especially Australia, the western Pacific and mid-Pacific islands, South Africa, Europe, the Russian Far East, and the eastern South Atlantic. Kirchenpauer was awarded an honorary doctorate from Universtät Kiel in 1876 for his scientific contributions. One family, one genus, and four species have been named in his honour.
\end{abstract}

Key words: biography, Bryozoa, Hydrozoa, marine biology, natural history, taxonomy, zoology

\section{Introduction}

Natural history was an avocation for several eighteenth and nineteenth century pioneers in the study of hydroids and bryozoans. Among them were clerics (John Fleming, 1785-1857; Thomas Hincks, 1818-1899; Alfred Merle Norman, 1831-1918), physicians (George Johnston, 1797-1855; Thomas Strethill Wright, 1818-1876), and merchants (John Ellis, 1710-1776; Joshua Alder, 1792-1867). Contributions to taxonomy of these groups by Gustav Heinrich Kirchenpauer, lawyer, journalist, statesman, historian, and seven-time Bürgermeister of the Freie und Hansestadt Hamburg (Free and Hanseatic City of Hamburg), are briefly addressed here. Kirchenpauer's hydrozoan work focused on leptothecate hydroids, especially plumularioids and sertularioids.

\section{Methods}

Publications by Kirchenpauer were compiled from the Royal Society of London Catalogue of Scientific Papers (1800-1863, 1864-1873, 1874-1883, 1884-1900), The Zoological Record (volumes 1-42), a bibliography on invertebrates by Thompson (1885), and bibliographic works on hydrozoans by Bedot (1910, 1912, 1916). Dates of publication were determined from the works in which they appeared, or from other sources.

Names of genus- and species-group taxa established by Kirchenpauer (Tables 1, 2) were taken from his publications, and from generic names included in Nomenclator Zoologicus. These are listed as originally established except for hyphenated specific names (Dynamena grosse-dentata; Aglaophenia multiplicato-pinnata), and one 
having an umlaut (Sertularella mülleri), which have been corrected. Incorrect subsequent spellings of available names, such as Aglaophemia for Aglaophenia Lamouroux, 1812 (Kirchenpauer 1876: 12), are not included.

\section{Family, Education, and Career}

Detailed accounts of the life and professional accomplishments of Kirchenpauer (Figs. 1A, B) are given by von Melle (1888), von Samson (1890), Wohlwill (1903), and Kraepelin (1908), among others. Only highlights of his career as provided in those works are summarized here.

Gustav Heinrich Kirchenpauer was born in Hamburg on 2 February 1808, the son of Johann Georg Kirchenpauer, a businessman, and his wife, Anna Catharina Ruess. Their family also included Johann Eduard (b. 1800, who became a property manager) and Julius (b. 1810, an engineer in Russia). Two other sons (b. 1804 and 1806) died in early childhood. Because of hardships at the time due to the Napoleonic occupation of Hamburg and continental embargo of the United Kingdom, the Kirchenpauer family moved in 1810 to St. Petersburg, Russia, home of Johann Georg's sister Julia and her husband, Jakob von Krause. Anna Catharina Kirchenpauer died after giving birth to Julius, and Johann Georg was often away on business. Jakob, a prosperous merchant, and Julia supported and educated their nephews. The extended family fled to London in the autumn of 1812 during the invasion of Russia by the Grande Armée of Napoleon. They returned to St. Petersburg in the summer of 1813, several months after the Napoleonic forces had retreated.

Kirchenpauer attended the Deutsche Schule of Johann von Muralt in St Petersburg. At age 15 he entered the deutsch-protestantisches Gymnasium (German Protestant High School) at Dorpat (Tartu) in Estonia, and in 1826 began studies in law and political science at Universität Dorpat. In early 1830 he entered Universität Heidelberg as a student of law, and received the degree of Doctor of Jurisprudence in 1831. After completing his education, Kirchenpauer spent several months in Dresden with his uncle Jakob before returning to Hamburg in 1832.

Back in his native city, Kirchenpauer opened a law practice and also worked as a journalist and editor. He specialized in commerce, particularly problems associated with import and export taxes of Hamburg as a Hanse city. With Hamburg being a major port, shipping and issues relating to that industry were an important part of his work. The interest likely led, indirectly, to his later investigations of fouling organisms on buoys ("Seetonnen") in the Elbe River (Kirchenpauer, 1862), and that project in turn is likely to have stimulated a scientific interest in hydroids. Somewhat later, the scope of his research extended to bryozoans. With a reputation for competence, selfreliance, and candor, Kirchenpauer's career advanced rapidly. In 1840 he became Librarian and Secretary of the Chamber of Commerce in Hamburg. When a disastrous fire raged through the city in May 1842, Kirchenpauer was credited with saving the building that housed the stock market. In 1843 he was elected to the senate of the city.

According to Jenkins (2003), Kirchenpauer was an avid student of history, a founding member in 1839 of the Verein für hamburgische Geschichte, and author of an historical account of the city's stock exchange (Kirchenpauer 1841). For many years he urged that local history be taught as a subject in secondary schools. A patriotic citizen of his birthplace and deeply committed to local sovereignty, he later undertook complex and at times heated negotiations with Otto Eduard Leopold von Bismarck (1815-1898) of Prussia over incorporation of Hamburg into the Deutsches Reich (German Empire). Hamburg became a Land of the Reich in 1871.

In 1844, Kirchenpauer married Julie Dorothea Krause (1818-1905), a relative of Jakob von Krause. The couple had three children: Gustav (1847-1914), who became an architect and served in the Sekretär der Deputation für Handel und Schiffahrt (Office of Trade and Navigation) in Hamburg; Flora, who married a German Consul (Dr Hermann Stannius); and Ulrich (1859-1905), who served as a military officer.

A prominent political figure by age 40, Kirchenpauer served in the Bundestag in Frankfurt am Main from 1848 to 1857, a period of political flux in the German states. On 6 June 1858 he was appointed Amtmann zu Ritzebüttel (magistrate of Ritzebüttel), now part of the city of Cuxhaven at the mouth of the Elbe River, and he occupied that post until 29 August 1864. The appointment in Ritzebüttel provided him with opportunities for investigations in natural history. After six years in Ritzebüttel he returned to Hamburg and represented the city in the Federal Council of the Norddeutscher Bund (North German Confederation) from 1867 to 1871, and in its replacement, the Deutsches Reich, from 1871 to 1880 . Meanwhile, he served as first or second Bürgermeister of the city seven times between 1869 and 1887 (Fig. 1B), and was active in transforming the educational system of Hamburg from one based on private schools to a system supported by the city-state. One noteworthy school there, the Kirchenpauer 
Gymnasium, was later named in his honour. Kirchenpauer also played an important role in the founding of Universität Hamburg.

He died at his desk as mayor on the evening of 3 March 1887, and was interred at Hamburg-Ohlsdorf cemetery in the city.

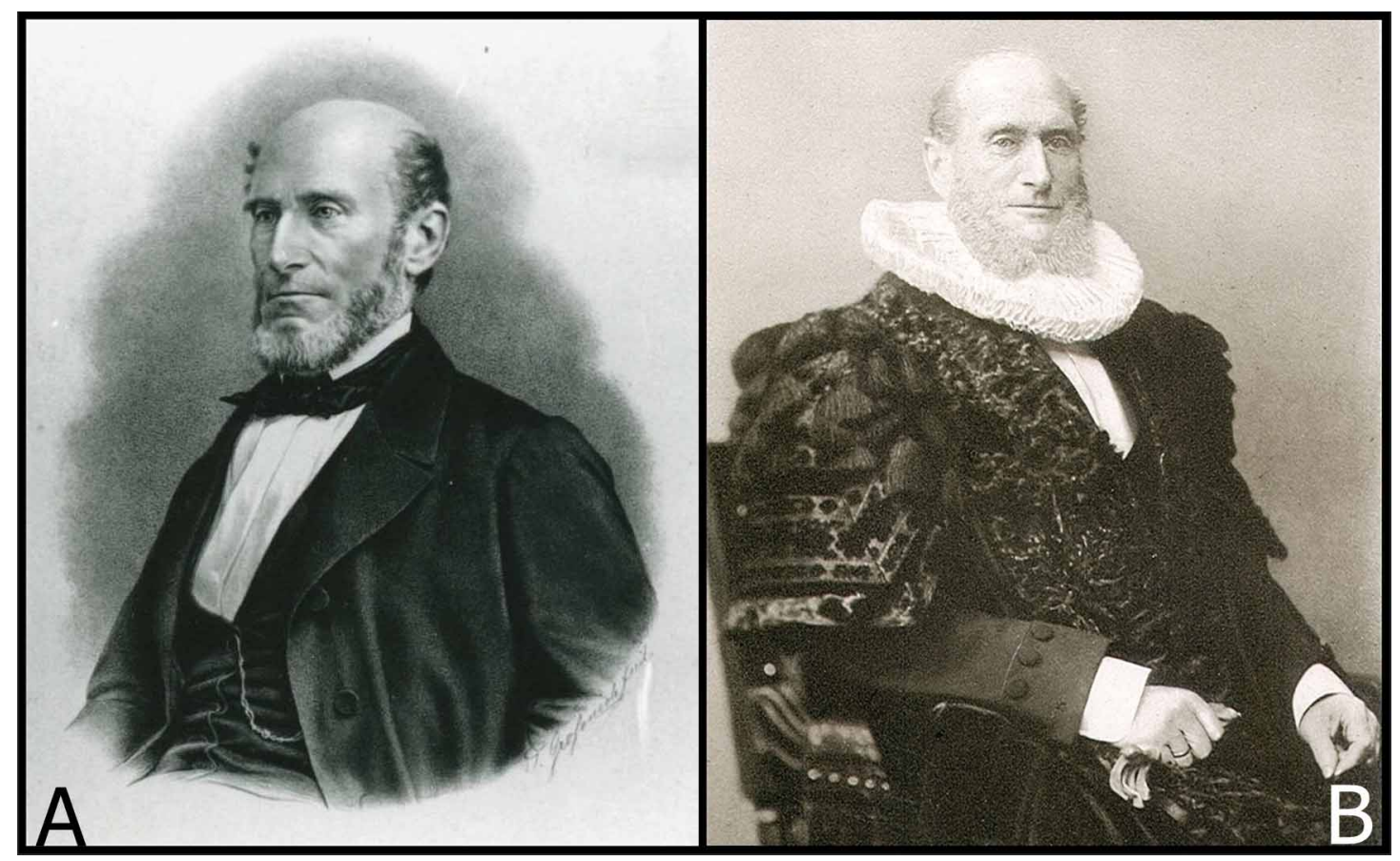

FIGURE 1. Gustav Heinrich Kirchenpauer, Bürgermeister of the Freie und Hansestad Hamburg, and taxonomist of hydroids and bryozoans. A, from Cuxhaven City Archives, photograph number 34C1-00170. B, from Wohlwill, 1903, in http://commons.wikimedia.org/wiki/File:Gustav_Heinrich_Kirchenpauer.jpg, last accessed 27 September 2010.

\section{Scientific work}

While serving as magistrate in Ritzebüttel, near the North Sea coast, Kirchenpauer began a study of marine invertebrates and algae collected from buoys in the Elbe River estuary. In a short paper authored by British zoophytologist George Busk (1861), with whom he had corresponded, Kirchenpauer described and named Cordylophora albicola, a hydroid he supposed to be new. Described in both Latin and English and accompanied by illustrations, his hydroid was later shown to be conspecific with C. caspia (Pallas, 1771) (Schuchert 2004).

In all, Kirchenpauer $(1862,1864,1872,1874,1876,1884)$ published six papers with information on hydroids over a two-decade period. ${ }^{1}$ In them he described eight new nominal genera and 77 new nominal species of hydroids, all but one (Cordylophora albicola) being leptothecates (Table 1). ${ }^{2}$ Kirchenpauer generally adhered to contemporary classification systems, and especially that followed by George James Allman (1812-1898) of the United Kingdom. While his illustrations were generally accurate, those made from dry specimens (Nutting 1900:60; 1904:96) reflect resulting distortions. Because a number of Kirchenpauer's descriptions are now known to be inadequate, it is impossible to identify with certainty some of the species he established (Millard 1975:5).

His first scientific publication (Kirchenpauer 1862) constituted an early study in marine biology and ecology. It was based on investigations of epibiota collected over several years from buoys in the Elbe River along an environmental gradient from open sea, off the river mouth, to low-salinity waters near the head of the estuary. This was the first study of its kind in the Elbe (Riedel-Lorjé and Gaumert 1982), and it provides useful baseline data about the

1. Written predominantly or entirely in German, Kirchenpauer's papers on hydroids totaled 255 pages. Latin descriptions, in telegraphic style, of supposed new genera and species were given in all but the last of these (Kirchenpauer 1884), in which both descriptions and general text were in German.

2. These include familiar genera such as Abietinaria, Macrorhynchia, and Lytocarpia, and widespread species such as Tridentata marginata (sometimes known by the binomen Sertularia marginata) and Macrorhynchia philippina. 
environmental state of the Elbe estuary at the time. Ecological observations on hydroids, crustaceans, worms, molluscs, echinoderms, sea anemones, and algae (including diatoms) of the estuary, as well as seasonal changes in assemblages of organisms, were discussed. Four regions were distinguished along the estuary based on characteristic hydroid species that grew on the buoys: a Sertularia argentea Region, seaward of the river mouth; a Tubularia larynx Region, in the lower reaches; a Laomedea gelatinosa Region, in the middle reaches; a Cordylophora albicola Region, in the upper reaches. These regions were correlated with the salinity gradient in the river. In the report Kirchenpauer discussed 10 species of hydroids, and it seems certain that his subsequent interest in taxonomy of the group grew out of this investigation.

In a period of less than five years, his natural history research expanded in geographic scope from regional to global, and the focus of his work shifted from general marine biology to taxonomy, especially of hydroids and bryozoans. His first systematic paper (Kirchenpauer 1864) was a review of the hydroid genus Dynamena Lamouroux, 1812 and some 30 species that he assigned to it. Eight of these species were described as new (Table 1), most of them having been found on algae collected from Australia and elsewhere in the Pacific Ocean.

TABLE 1. Names of Hydrozoa proposed by G.H. Kirchenpauer. The letter "K" = Kirchenpauer. Names with an asterisk are currently held to be valid.

*Abietinaria K, 1884 [type species: Sertularia abietina Linnaeus, 1758, by original designation]

Anisocola K, 1872 [type species: Sertularia setacea Linnaeus, 1758, by subsequent designation by Calder (1997)]

Calathophora K, 1872 [type species: Sertularia pluma Linnaeus, 1758, by original designation]

Isocola K, 1872 [type species: Aglaophenia gaimardi Lamouroux, 1824, by subsequent designation by Calder (1997)]

*Lytocarpia K, 1872 [type species: Aglaophenia myriophyllum Linnaeus, 1758, by original designation]

*Macrorhynchia K, 1872 [type species: Macrorhynchia savignyana Kirchenpauer, 1872, by original designation]

Pachyrhynchia K, 1872 [type species: Aglaophenia cupressina Lamouroux, 1816, by subsequent designation by Calder (1997:

50)]

Pluriserialia K, 1876 [type species: none yet designated]

Abietinaria cartilaginea $\mathrm{K}, 1884$

Bering Sea or Kamchatka

*Abietinaria juniperus $\mathrm{K}, 1884$

Kuril Islands

*Abietinaria melo K, 1884

Kuril Islands

*Abietinaria merkii K, 1884

Russia: Kamchatka

Abietinaria tilesii K, 1884

Russia: Kamchatka

Aglaophenia (Calathophora) alopecura K, 1872

South Africa

Aglaophenia (Calathophora) avicularis K, 1872

Australia: Hobart

Aglaophenia (Calathophora) conferta K, 1872

South Africa: Cape of Good Hope

Aglaophenia (Calathophora) huttoni K, 1876

New Zealand: Lyall Bay

Aglaophenia (Calathophora) plumifera K, 1872

South Africa: Algoa Bay

Aglaophenia (Calathophora) pusilla K, 1872

South Africa: Algoa Bay

Aglaophenia (Calathophora) vitiana K, 1872

Fiji

Aglaophenia (Lytocarpia) crispata K, 1872

Indonesia: Java. Taiwan

*Aglaophenia (Lytocarpia) lignosa K, 1872 (now Cladocarpus)

South Africa: Cape of Good Hope

(?)Aglaophenia (Lytocarpia) secunda K, 1872

Pacific Ocean. China Sea. Palau

Aglaophenia (Macrorhynchia) brevicaulis K, 1872

Australia: Ballina

Aglaophenia (Macrorhynchia) fusca K, 1872

South Africa: Cape of Good Hope

Aglaophenia (Macrorhynchia) ligulata K, 1872

South Africa: Algoa Bay

*Aglaophenia (Macrorhynchia) longirostris K, 1872 (now Gymnangium) Australia: Wilson's Promontory

Aglaophenia (Macrorhynchia) patula K, 1872

South Africa: Cape of Good Hope

*Aglaophenia (Macrorhynchia) philippina K, 1872

Philippines: Manila

Aglaophenia (Macrorhynchia) ramulosa K, 1872

Australia: Port Lincoln

Aglaophenia (Macrorhynchia) rostrata K, 1872

Singapore 
TABLE 1. (continued)

\begin{tabular}{|c|c|}
\hline Aglaophenia (Macrorhynchia) rubens K, 1872 & Australia: Port Denison \\
\hline Aglaophenia (Macrorhynchia) savignyana K, 1872 & Adriatic Sea (?) \\
\hline Aglaophenia (Macrorhynchia) squarrosa K, 1872 & Australia: Port Denison \\
\hline Aglaophenia (Macrorhynchia) urens K, 1872 & Indonesia: Java Sea; Batang. Australia: Brisbane \\
\hline Cordylophora albicola $\mathrm{K}$, in Busk, 1861 & Germany: Elbe River \\
\hline *Dynamena australis K, 1864 (now Sertularia) & Australia: Port Phillip \\
\hline *Dynamena conferta K, 1864 (now Sertularia) & Australia: Carpentaria \\
\hline *Dynamena fasciculata K, 1864 (now Amphisbetia) & Australia: Sydney. New Zealand \\
\hline *Dynamena grossedentata K, 1864 (now Amphisbetia) & Australia \\
\hline Dynamena lucernaria K, 1864 & Marquesas Islands: Nukahiva \\
\hline *Dynamena marginata K, 1864 (now Tridentata) & Pacific Ocean \\
\hline Dynamena penna K, 1864 & Australia: Tasmania \\
\hline Dynamena pleuridentata K, 1864 & South Africa: Cape of Good Hope \\
\hline Nemertesia (Antennularia) antennina v. minor K, 1876 & Madeira \\
\hline Nemertesia (Antennularia) decussata K, 1876 & South Africa: Cape of Good Hope \\
\hline *Nemertesia (Antennularia) hexasticha K, 1876 & Indonesia: Java \\
\hline Nemertesia (Antennularia) johnstoni K, 1876 & South Africa: Algoa Bay \\
\hline *Nemertesia (Antennularia) paradoxa $\mathrm{K}, 1876$ & Madeira \\
\hline *Nemertesia (Heteropyxis) intermedia $\mathrm{K}, 1876$ & Madeira \\
\hline *Plumularia (Anisocola) filicaulis K, 1876 & Chile: Talcahuano \\
\hline Plumularia (Anisocola) halecioides var. adriatica K, 1876 & Adriatic Sea \\
\hline Plumularia (Anisocola) oligopyxis K, 1876 & Fiji \\
\hline *Plumularia (Anisocola) rugosa K, 1876 & "in maribus Europae" \\
\hline *Plumularia (Isocola) badia K, 1876 & Australia: Brisbane. Singapore \\
\hline *Plumularia (Isocola) cylindrica K, 1876 & Indonesia: Java. Philippines \\
\hline Plumularia (Isocola) obconica K, 1876 & Australia: Gulf St. Vincent \\
\hline *Plumularia (Isocola) tuba K, 1876 (now Halopteris) & South Africa: Algoa Bay \\
\hline *Plumularia (Monopyxis) obliqua var. australis K, 1876 & Australia: Port Phillip \\
\hline *Selaginopsis urceolifera K, 1884 (now Staurotheca) & Kerguelen \\
\hline *Sertularella albida K, 1884 & USA: Shumagin Islands (Yukon Harbor) \\
\hline Sertularella arborea K, 1884 & South Africa: Algoa Bay; Cape of Good Hope \\
\hline Sertularella contorta K, 1884 & Falkland Islands: Lemaire Channel \\
\hline Sertularella fruticulosa K, 1884 & Russia: Kamchatka \\
\hline Sertularella muelleri K, 1884 & Australia: Chatham Island \\
\hline *Sertularella pallida K, 1884 (now Symplectoscyphus) & Unalaska \\
\hline Sertularella purpurea K, 1884 & Australia: Chatham Island \\
\hline *Sertularella reticulata K, 1884 (now Dictyocladium) & Australia: Bass Strait \\
\hline *Sertularella secunda K, 1884 (now Symplectoscyphus) & South Africa: Cape of Good Hope \\
\hline Sertularella sieboldi K, 1884 & Cuba \\
\hline Sertularella sonderi $\mathrm{K}, 1884^{1}$ & no provenance given \\
\hline *Sertularella spinosa $\mathrm{K}, 1884$ & Japan: Yokohama, Nagasaki \\
\hline Sertularella squamata K, 1884 & Strait of Magellan \\
\hline *Sertularella tilesii K, 1884 & "Nordostlichen Meeren" \\
\hline
\end{tabular}


TABLE 1. (continued)

\begin{tabular}{ll}
\hline Sertularella tricuspidata var. acuminata $\mathrm{K}, 1884$ & Russia: Kamchatka \\
*Thuiaria acutiloba $\mathrm{K}, 1884$ (now Salacia) & Kuril Islands or Kamchatka \\
*Thuiaria annulata $\mathrm{K}, 1884$ (now Abietinaria) & no provenance given \\
Thuiaria cartilaginea $\mathrm{K}, 1884$ & Australia: New South Wales \\
Thuiaria doliolum $\mathrm{K}, 1884$ & South Africa: Cape of Good Hope \\
$*$ Thuiaria elegans $\mathrm{K}, 1884$ (now Amphisbetia) & Bering Sea \\
$*$ Thuiaria polycarpa $\mathrm{K}, 1884$ (now Parathuiaria) & Chile: Valparaiso \\
$*$ Thuiaria stelleri $\mathrm{K}, 1884$ (now Thuiaria) & Russia: Kamchatka \\
& \\
Aglaophenia (Calathophora) graeffii $\mathrm{K}, 1876^{2}$ & South-sea Islands \\
Aglaophenia (Calathophora) phyteuma $\mathrm{K}, 1876^{2}$ & Tonga \\
Aglaophenia (Calathophora) tenerrima $\mathrm{K}, 1876^{2}$ & Chile \\
Aglaophenia (Calathophora) tongensis $\mathrm{K}, 1876^{2}$ & South-sea Islands \\
Aglaophenia (Macrorhynchia) multiplicatopinnata $\mathrm{K}, 1876^{2}$ & Red Sea \\
Aglaophenia (Macrorhynchia) pansa $\mathrm{K}, 1876^{2}$ & Tonga \\
Aglaophenia (Macrorhynchia) perforata $\mathrm{K}, 1876^{2}$ & Tonga
\end{tabular}

Aglaophenia opposita $\mathrm{K}$ ms, in Studer, $1889^{3}$

western Australia

\begin{abstract}
${ }^{1}$ The original account of Sertularella sonderi included only an illustration and its figure caption (Kirchenpauer (1884: plate 16, fig. 4), but that is sufficient to make the name available (ICZN Art. 12.2.7). It was included as a synonym of Sertularella neglecta Thompson, 1879 [Symplectoscyphus neglectus] by Bale (1915).

${ }^{2}$ These seven names are nomena nuda; Kirchenpauer (1876) provided neither descriptions, nor illustrations, nor "indications," for them (ICZN Art. 12.1, International Commission on Zoological Nomenclature 1999). Aglaophenia graeffii Kirchenpauer, 1876 and A. perforata Kirchenpauer, 1876 had been recognized earlier as nomena nuda (Calder 1997; Schuchert 2003). All were subsequently made available by Stechow (1919), who provided descriptions and illustrations of them, and they take authorship and date from that publication. Names as established for these hydroids by Stechow were: Lytocarpia graeffei (not as graeffii), Thecocarpus phyteuma, Aglaophenia tenerrima, Aglaophenia tongensis [included as a synonym of Thecocarpus brevirostris (Busk, 1852)], Lytocarpia multiplicatopinnata, Halicornaria pansa, and Aglaophenia perforata [included as a synonym of Lytocarpia philippina (Kirchenpauer, 1872)].

${ }^{3}$ The name Aglaophenia opposita, from an unpublished manuscript by Kirchenpauer but listed in Studer (1889) without description, definition, illustration, or indication, is a nomen nudum.
\end{abstract}

In the 1870 s, Kirchenpauer published two landmark works on plumularioid hydroids. ${ }^{3}$ Charles Cleveland Nutting (1900:3), an American hydroid specialist, credited him as being one of the leading contributors to knowledge of the group. The first work (Kirchenpauer 1872), a study of Aglaophenia Lamouroux, 1812, included accounts of four new subgenera and 21 new species (Table 1). Two of the subgenera are now recognized at the rank of genus (Lytocarpia and Macrorhynchia). The second paper (Kirchenpauer 1876) dealt with Plumularia Lamarck, 1816 and Nemertesia Lamouroux, 1812. Fifteen new species and varieties were named and described (Table 1), and a new name (Aglaophenia huttoni) was given to a species from New Zealand that had been misidentified as Plumularia pennatula (Ellis and Solander 1786) by Hutton (1873). In between these two reports, Kirchenpauer (1874) contributed an account of four species of hydroids collected during the Zweite Deutsche Nordpolarfahrt (Second German North Polar Expedition) in 1869-1870.

His final work on hydroids (Kirchenpauer 1884), published when he was 76 years old, was a revision of genera and species of Sertulariidae from high latitudes in the Northern Hemisphere. ${ }^{4}$ In it, one new genus (the now widely-

3. Plumularioid hydroids are defined by Cornelius (1995) as “...the group of thecates with uniseriate hydrothecae.” Included are four families, Aglaopheniidae, Halopterididae, Kirchenpaueriidae, and Plumulariidae. A familiar genus in the group is Plumularia.

4. Sertulariidae is a large family of hydroids, especially well represented in colder waters. Most are characterized by having biseriate, cusped, operculate hydrothecae (Cornelius 1995). A familiar genus in the family is Sertularia Linnaeus, 1758. 
known and species-rich Abietinaria) and 31 new species and varieties were described (Table 1). Over half of these new nominal species were assigned to Sertularella Gray, $1848 .{ }^{5}$

Like contemporaries including George Busk (1807-1886) and Thomas Hincks (1818-1899) of Great Britain, Kirchenpauer published on taxonomy of bryozoans (Kirchenpauer 1869, 1874, 1875, 1879) as well as hydroids. However, his works on Bryozoa, spanning only 73 pages excluding plates, constitute a relatively minor contribution to knowledge of the group. One new genus name (Retihornera Kirchenpauer, 1869) and 26 new species-group names were established in them (Table 2). His most thorough work on bryozoans was on species of Adeona Lamouroux, 1812, collected during the Expedition of S.M.S. Gazelle in 1874-1876 (Kirchenpauer 1879). That paper included a systematic account of 10 species-group taxa, including six described as new, together with discussion of colony morphology in the group. His first publication on bryozoans (Kirchenpauer 1869) had provided an account of material at the Museum Godeffroy, Hamburg, most of it collected in Australia and Pacific islands by German ship captains. Published in the rare Museum Godeffroy Catalog series (Evenhuis 2007), one new genus and 14 new species were introduced in the work (Table 2). Five years later, he wrote a taxonomic account based on a small collection of hydroids and bryozoans collected in Greenland during the Second German North Polar Expedition (Kirchenpauer 1874). The following year, he published a report on 53 species of Bryozoa (including 39 cheilostomes, eight cyclostomes, and seven ctenostomes) and one species of Entoprocta collected in the North Sea during 1872 by the vessel Pommerania (Kirchenpauer 1875). He paid particular attention to species and forms of the genus Flustra Linnaeus, 1761 in the collection. Before his death Kirchenpauer was preparing a manuscript on Bryozoa (exclusive of Adeona and its species) collected during the voyage of the Gazelle, but it was never published. $^{6}$

TABLE 2. Names of Bryozoa proposed by G.H. Kirchenpauer. The letter "K" = Kirchenpauer. Names with an asterisk are currently held to be valid.

\begin{tabular}{ll}
\hline Retihornera $\mathrm{K}, 1869$ [type species: none yet designated] & \\
\cline { 2 - 2 } *Adeona albida $\mathrm{K}, 1880$ & northwestern Australia: Mermaid Strait \\
*Adeona arborescens $\mathrm{K}, 1880$ & western Australia: Dirk Hartog Island \\
Adeona cellulosa var. ochracea $\mathrm{K}, 1880$ & Australia \\
*Adeona foliacea var. fascialis $\mathrm{K}, 1880$ & western Australia: Dirk Hartog Island \\
*Adeona intermedia $\mathrm{K}, 1880$ & South Africa: Algoa Bay \\
*Adeona macrothyris $\mathrm{K}, 1880$ & northwestern Australia \\
Cellepora tridens $\mathrm{K}, 1875$ & North Sea \\
*Eschara reniformis $\mathrm{K}, 1869$ (now Parmularia) & Australia: Gulf St. Vincent \\
Eschara spongiaeformis $\mathrm{K}, 1869$ & Australia: Gulf St. Vincent \\
Farciminaria punctata $\mathrm{K}, 1869$ & South Africa \\
Flustra dichotoma $\mathrm{K}, 1875$ & North Sea \\
Hemeschara contorta $\mathrm{K}, 1874$ & east Greenland: north of Shannon Island \\
*Hornera australis $\mathrm{K}, 1869$ & Australia: Bass Strait \\
Idmonea flabellata $\mathrm{K}, 1869$ & Australia: Gulf St. Vincent \\
$*$ Lepralia smittii $\mathrm{K}, 1874$ (now Smittina) & Spitzbergen. Norway \\
Onchopora salicornioides $\mathrm{K}, 1869$ & Fiji \\
\hline
\end{tabular}
continued next page

5. Kirchenpauer recognized two groups of species in the genus Sertularella as then understood, a "Sertularella polyzonias" group having four or five marginal cusps on the hydrothecal rim, and a "Sertularella tricuspidata" group with three marginal cusps. The latter group was later recognized as constituting a separate genus, Symplectoscyphus Marktanner-Turneretscher, 1890.

6. Names of 20 putative new species from Kirchenpauer's manuscript on Bryozoa were listed in a report on results of the Gazelle Expedition by Studer (1889), but all are nomena nuda. The name Dendrofascipora applied by Kirchenpauer to three species of Bryozoa in Studer's report, if intended for a new genus, is also unavailable from that work. Studer included three other binomina that he attributed to Kirchenpauer, but all three names had been established earlier by other authors (Scrupocellaria gracilis Reuss, 1869, Lepralia crassilabra Manzoni, 1875, and Vincularia labiata Busk, 1884). 
TABLE 2. (continued)

\begin{tabular}{|c|c|}
\hline Retihornera affinis K, 1869 & Fiji \\
\hline Retihornera corbicula K, 1869 & Australia: Bass Strait \\
\hline Retihornera dentata K, 1869 & Australia: Bass Strait \\
\hline *Retihornera graeffei K, 1869 (now Reteporella) & Fiji \\
\hline Retihornera parasitica K, 1869 & Australia: Gulf St. Vincent \\
\hline Retihornera plicata K, 1869 & Australia: Gulf St. Vincent \\
\hline *Salicornaria pilosa K, 1869 (now Cellaria) & Australia: Bass Strait \\
\hline *Serialaria semispiralis K, 1869 (now Amathia) & Samoa \\
\hline Hornera lichenoides forma flabellaris K, 1874 & east Greenland \\
\hline *Hornera lichenoides forma reticulata K, 1874 & east Greenland \\
\hline Catenicella amphotis $\mathrm{K}$ ms, in Studer, $1889^{4}$ & western Australia \\
\hline Cellaria inflata $\mathrm{K} \mathrm{ms}$, in Studer, $1889^{4}$ & northwestern Australia \\
\hline Cellaria labellata K ms, in Studer, $1889^{4}$ & northern New Zealand \\
\hline Cupularia perforata $\mathrm{K}$ ms, in Studer, $1889^{4}$ & Liberia \\
\hline Dendrofascipora dichotoma $\mathrm{K}$ ms, in Studer, $1889^{4}$ & northern New Zealand: Three Kings Islands \\
\hline Dendrofascipora simplex $\mathrm{K}$ ms, in Studer, $1889^{4}$ & northern New Zealand \\
\hline Dendrofascipora spinosa K ms, in Studer, $1889^{4}$ & northern New Zealand \\
\hline Eschara perosa $\mathrm{K}$ ms, in Studer, $1889^{4}$ & Liberia \\
\hline Gemellaria cyclostoma $\mathrm{K}$ ms, in Studer, $1889^{4}$ & northern New Zealand \\
\hline Lepralia megapora $\mathrm{K}$ ms, in Studer, $1889^{4}$ & western Australia \\
\hline Menipea gazellae K ms, in Studer, $1889^{4}$ & Kerguelen \\
\hline Menipea simplex $\mathrm{K}$ ms, in Studer, $1889^{4}$ & Argentina \\
\hline Menipea studeri $\mathrm{K}$ ms, in Studer, $1889^{4}$ & Argentina \\
\hline Menipea vibracularis $\mathrm{K}$ ms, in Studer, $1889^{4}$ & Argentina \\
\hline Pustulipora spiralis $\mathrm{K}$ ms, in Studer, $1889^{4}$ & western Australia. northern New Zealand \\
\hline Pustulipora verticillata $\mathrm{K}$ ms, in Studer, $1889^{4}$ & western Australia \\
\hline Retihornera flabellum K ms, in Studer, $1889^{4}$ & Kerguelen \\
\hline Salicornaria avicularis K ms, in Studer, $1889^{4}$ & Kerguelen \\
\hline Selenaria expleta K ms, in Studer, $1889^{4}$ & northern New Zealand \\
\hline Tubucellaria meridionalis $\mathrm{K}$ ms, in Studer, $1889^{4}$ & northwestern Australia \\
\hline
\end{tabular}

${ }^{4}$ The manuscript by Kirchenpauer in which these 20 binomena were introduced was never published. Names from that manuscript were listed by Studer (1889), but without descriptions, illustrations, or indications. All are nomena nuda.

In addition to his own publications on hydroids and bryozoans, Kirchenpauer provided identifications of the two groups in works by several others (von Heuglin 1874; von Muller 1884; Studer 1889).

Kirchenpauer is sometimes cited as author of the generic name Kirchenpaueria, as applied to Bryozoa. However, he quoted it only as a manuscript name used in an unpublished work by Graeffe (Kirchenpauer 1869: page $\mathrm{xxx}$ ) and was not attempting to name a genus after himself. As a nomen nudum, it does not threaten the name Kirchenpaueria Jickeli, 1883, currently valid for a genus of Hydrozoa.

Types of new species of plumularioid hydroids founded by Kirchenpauer $(1872,1876)$ were later examined and illustrated by Stechow (1919). Stechow's account is particularly important because most of the Kirchenpauer collection was lost during the Second World War (Millard 1975:5, 415). Some types of species from Australia exist in the Museum Victoria, Melbourne. ${ }^{7}$ Much of the Kirchenpauer collection of Bryozoa was also apparently destroyed during the war (Cook 1965), although some material from the Gazelle Expedition exists in the Museum für Naturkunde, Berlin (Cook and Chimonides 1984). 
On 7 April 1875 Kirchenpauer became a member of the Kaiserlichen Leopoldino-Carolinischen Deutschen Akademie der Naturforscher (Leopoldina 11:53) and he remained so until his death in 1887 (Leopoldina 23:42, 58). In addition to numerous honours for distinguished public service, he was awarded an honorary doctorate from Universität Kiel for his contributions to science. He characteristically remained modest about the honour, stating with regard to his scientific discoveries that even a blind chicken occasionally finds a kernel of grain (“...findet ein blindes Huhn: auch wol einmal ein Korn").

Although Kirchenpauer's final paper in natural history was published in 1884, his research is still mentioned in current scientific literature. Citations of his work in 16 papers since 2000 were recorded in the "Cited Reference Index" of "Web of Science" "with five each of the works on Aglaophenia (Kirchenpauer 1872) and northern Sertulariidae (Kirchenpauer 1884). The most frequently cited publications by Kirchenpauer in works between 1900 and early 2010 were his papers on northern Sertulariidae (Kirchenpauer 1884:10 times), on Aglaophenia (Kirchenpauer 1872:8 times), on fouling organisms of the Elbe estuary (Kirchenpauer 1862:6 times) and on Plumularia and Nemertesia (Kirchenpauer 1876:6 times).

One family, Kirchenpaueriidae Stechow, 1921 (Hydrozoa), one genus, Kirchenpaueria Jickeli, 1883 (Hydrozoa), and four species, Lepralia kirchenpaueri Heller, 1867 (Bryozoa; now Hagiosynodos kirchenpaueri), Plumularia kirchenpaueri Heller, 1868 (Hydrozoa; now Aglaophenia kirchenpaueri), Thuiaria kirchenpaueri Marktanner-Turneretscher, 1895 (Hydrozoa; now a synonym of Thuiaria carica Levinsen, 1893), and Nesotragus kirchenpaueri Pagenstecher, 1885 [Mammalia; now a synonym of Nesotragus moschatus (von Dueben, in Sundevall, 1846)], are named in his honour.

\section{Acknowledgements}

We are grateful to Judith Winston (Virginia Museum of Natural History) and Priska Schäfer (Institut für Geowissenschaften der Universität Kiel) for help in obtaining an obscure publication on Bryozoa by Kirchenpauer (1875). Lars Schmidt (Stadarchiv Cuxhaven) provided one of the photographs used herein. Sincere thanks are expressed to Lester Stephens (University of Georgia) and an anonymous referee for helpful comments, and to Allen Collins (National Museum of Natural History, Smithsonian Institution) for editing the manuscript.

\section{References}

Bale, W.M. (1915) Report on the Hydroida collected in the Great Australian Bight and other localities. Part III. Biological Results of the Fishing Experiments Carried on by the F.I.S. "Endeavour," 1909-14, 3, 241-336.

Bedot, M. (1910) Matériaux pour servir à l'histoire des hydrö̈des. $3^{\text {me }}$ période (1851 à 1871). Revue Suisse de Zoologie, 18, $189-490$.

Bedot, M. (1912) Matériaux pour servir à l'histoire des hydroïdes. $4^{\mathrm{me}}$ période (1872 à 1880). Revue Suisse de Zoologie, 20 , 213-469.

Bedot, M. (1916) Matériaux pour servir à l'histoire des hydroïdes. $5^{\mathrm{e}}$ période (1881 à 1890). Revue Suisse de Zoologie, 24, 1349.

Busk, G. (1852) An account of the Polyzoa, and sertularian zoophytes, collected in the voyage of the Rattlesnake, on the coasts of Australia and the Louisiade Archipelago, \&c, Volume 1, Appendix No. 4. In: Macgillivray, J., Narrative of the Voyage of H.M.S. Rattlesnake, Commanded by the late Captain Owen Stanley, R.N., F.R.S. \& c. During the Years 1846-1850. T. \& W. Boone, London, pp. 343-402.

Busk, G. (1861) On a new hydroid polype belonging to the genus Cordylophora, Allm., discovered by Senator Kirchenpauer, of Ritzebüttel. Quarterly Journal of Microscopical Science, new series, 1, 283-284.

Busk, G. (1884) Report on the Polyzoa collected by H.M.S. Challenger during the years 1873-76. Part I.-The Cheilostomata. Report on the Scientific Results of the Voyage of H.M.S. Challenger during the Years 1873-76, Zoology, 10(30), 1-216.

Calder, D.R. (1997) Shallow-water hydroids of Bermuda: superfamily Plumularioidea. Royal Ontario Museum, Life Sciences Contributions, 161, 1-85.

7. (http://museumvictoria.com.au/collections-research/our-collections/science-collections/invertebrates/sessile-and-planktonic/, last accessed 23 February 2010).

8. (ISI Web of Knowledge, Thomson Reuters Corporation, http://www.isiwebofknowledge.com; survey undertaken 25 February 2010). 
Cook, P.L. (1965) Notes on the Cupuladriidae (Polyzoa, Anasca). Bulletin of the British Museum (Natural History), Zoology, 13, 151-187.

Cook, P.L. \& Chimonides, P.J. (1984) Recent and fossil Lunulitidae (Bryozoa: Cheilostomata) 1. The genus Otionella from New Zealand. Journal of Natural History, 18, 227-254.

Cornelius, P.F.S. (1995) North-west European thecate hydroids and their medusae. Part 2. Sertulariidae to Campanulariidae. Synopses of the British Fauna, new series, 50, 386 pp.

Dueben, W. von. \& in Sundevall, C.J. (1846) Ny antelop art. Öfversigt af Kongliga Vetenskaps-Akademiens Förhandlingar, 3, $221-222$.

Ellis, J. \& Solander, D. (1786) The natural history of many curious and uncommon zoophytes, collected from various parts of the globe by the late John Ellis... Systematically arranged and described by the late Daniel Solander... Benjamin White \& Son, \& Peter Elmsly, London, 206 pp.

Evenhuis, N.L. (2007) The Godeffroy Museum catalogs in relation to Fiji terrestrial arthropods. Part I: Introduction and review of Myriapoda, Diptera, Odonata, and smaller hexapod orders. Bishop Museum Occasional Papers, 91, 17-28.

Gray, J.E. (1848) List of the specimens of British animals in the collection of the British Museum. Part I. Centroniae or radiated animals. British Museum, London, $173 \mathrm{pp}$.

Heller, C. (1867) Die Bryozoën des adriatischen Meeres. Verhandlungen der Kaiserlich-Königlichen Zoologisch-Botanischen Gesellschaft in Wien, 17, 77-136.

Heller, C. (1868) Die Zoophyten und Echinodermen des Adriatischen Meeres. Verhandlungen der Kaiserlich-Königlichen Zoologisch-Botanischen Gesellschaft in Wien, 18, 1-88.

Heuglin, T. von (1874) Quallen (Coelenterata). In: Reisen nach dem Nordpolarmeer in den Jahren 1870 und 1871. Dritter Theil. Verlag von George Westermann, Braunschweig, pp. 259-260.

Hutton, F.W. (1873) On the New Zealand sertularians. Transactions and Proceedings of the New Zealand Institute, 5, $256-259$.

International Commission on Zoological Nomenclature (1999) International code of zoological nomenclature. Fourth edition. International Trust for Zoological Nomenclature, London, $306 \mathrm{pp}$.

Jenkins, J. (2003) Provincial modernity: local culture and liberal politics in fin-de-siècle Hamburg. Cornell University Press, Ithaca, New York, 329 pp.

Jickeli, C.F. (1883) Der Bau der Hydroidpolypen. II. Über den histiologischen Bau von Tubularia L., Cordylophora Allm., Cladonema Duj., Coryne Gärtn., Gemmaria M'Crady, Perigonimus Sars, Podocoryne Sars, Camponopsis Claus, Lafoëa Lam., Campanularia Lam., Obelia Pér., Anisocola Kirchenp., Isocola Kirchenp., Kirchenpaueria Jick. Morphologisches Jahrbuch, 8, 850-680.

Kirchenpauer, G.H. (1841) Die alte Börse, ihre Gründer und ihre Vorsteher. Ein Beitrag zur hamburgischen Handelsgeschichte. Hamburg. [Not seen]

Kirchenpauer, G.H. (1862) Die Seetonnen der Elbmündung. Ein Beitrag zur Thier- und Pflanzen-Topographie. Abhandlungen aus dem Gebiete der Naturwissenschaften, herausgegeben von dem Naturwissenschaftlichen Verein in Hamburg, 4(3), 159.

Kirchenpauer, G.H. (1864) Neue Sertulariden aus verschiedenen Hamburgischen Sammlungen, nebst allgemeinen Bemerkungen über Lamouroux's Gattung Dynamena. Verhandlungen der Kaiserlichen Leopoldino-Carolinischen Deutschen Akademie der Naturforscher, 31(3), 1-16.

Kirchenpauer, G.H. (1869) Neue Bryozoen. Museum Godeffroy, Catalog IV, xxv-xxxiv.

Kirchenpauer, G.H. (1872) Ueber die Hydroidenfamilie Plumularidae, einzelne Gruppen derselben und ihre Fruchtbehälter. I. Aglaophenia Lx. Abhandlungen aus dem Gebeite der Naturwissenschaften herausgegeben von dem Naturwissenschaftlichen Verein in Hamburg, 5(3), 1-52.

Kirchenpauer, G.H. (1874) Hydroiden und Bryozoën. In: Die Zweite Deutsche Nordpolarfahrt in den Jahren 1869 und 1870 unter Führung des Kapitän Karl Koldewey. Herausgegeben von dem Verein für die Deutsche Nordpolarfahrt in Bremen. Zweiter Band. Wissenschaftliche Ergebnisse. Erste Abtheilung. F.A. Brockhaus, Leipzig, 2(1), 411-428.

Kirchenpauer, G.H. (1875) Zoologische Ergebnisse der Nordseefahrt von 21 Juli bis 9 September 1872. Bericht über die Untersuchungsfahrt der Pommerania in der Nordsee, 1872. VI. Bryozoa. Jahresbericht der Commission zur Wissenschaftlichen Untersuchung der Deutschen Meere in Kiel, 2 \& 3, 173-196.

Kirchenpauer, G.H. (1876) Ueber die Hydroidenfamilie Plumularidae, einzelne Gruppen derselben und ihre Fruchtbehälter. II. Plumularia und Nemertesia. Abhandlungen aus dem Gebiete der Naturwissenschaften herausgegeben vom Naturwissenschaftlichen Verein zu Hamburg-Altona, 6(2), 1-59.

Kirchenpauer, G.H. (1879) Ueber die Bryozoen-Gattung Adeona. Journal des Museum Godeffroy, 1879, 24 pp.

Kirchenpauer, G.H. (1884) Nordische Gattungen und Arten von Sertulariden. Abhandlungen aus dem Gebeite der Naturwissenschaften herausgegeben vom Naturwissenschaftlichen Verein in Hamburg, 8(3), 93-144.

Kraepelin, K. (1908) Zum Gedächtnis Gustav Heinrich Kirchenpauer's. Verhandlungen des Naturwissenschaftlichen Vereins in Hamburg, Dritte Folge, 15, 81-89.

Lamarck, J.B.P.A. de (1816) Histoire naturelle des animaux sans vertèbres. Tome 2. Verdière, Paris, 568 pp.

Lamouroux, J.V.F. (1812) Extrait d'un mémoire sur la classification des polypiers coralligènes non entièrement pierreux. Nouveau Bulletin des Sciences, par la Société Philomatique de Paris, 3, 181-188.

Lamouroux, J.V.F. (1816) Histoire des polypiers coralligènes flexibles, vulgairement nommés zoophytes. F. Poisson, Caen, 559 pp. 
Lamouroux, J.V.F. (1924) Description des polypiers flexibles. In: Quoy, J.R.C., \& Gaimard, J.P. (Eds.), Voyage autour du monde, entrepris par ordre du Roi, exécuté sur les corvettes de S. M. l'Uranie et la Physicienne, pendant les années 1817, 1818, 1819 et 1820. Zoologie. Pillet Aîné, Paris, pp. 603-643.

Levinsen, G.M.R. (1893) Om en ny Thujaria-art fra Kara-Havet. Thujaria carica nov. sp. Videnskabelige Meddelelser fra den Naturhistoriske Forening i Kjфbenhavn, series 5, 4, 213-214.

Linnaeus, C. (1758) Systema naturae per regna tria naturae, secundum classes, ordines, genera, species cum characteribus, differentiis, synonymis, locis. Editio decima, reformata. Laurentii Salvii, Holmiae, 823 pp.

Linnaeus, C. (1761) Fauna Suecica, sistens animalia Sueciae regni: Mammalia, Aves, Amphibia, Pisces, Insecta, Vermes. Distributa per classes \& ordines, genera \& species, cum differentiis specierum, synonymis auctorum,nominibus incolarum, locis natalium, descriptionibus insectorum. Editio altera, auctior. Laurentii Salvii, Stockholmiae, 544 pp.

Manzoni, A. (1875) I briozoi del Pliocene antico di Castrocaro. Gamberini \& Parmeggiani, Bologna, 64 pp.

Marktanner-Turneretscher, G. (1890) Die Hydroiden des K. K. Naturhistorischen Hofmuseums. Annalen des K.K. Naturhistorischen Hofmuseums, 5, 195-286.

Marktanner-Turneretscher, G. (1895) Zoologische Ergebnisse der im Jahre 1889 auf Kosten der Bremer geographischen Gesellschaft von Dr. Willy Kükenthal und Dr. Alfred Walter ausgeführten Expedition nach Ost-Spitzbergen. Hydroiden. Zoologische Jahrbücher, Abtheilung für Systematik, Geographie und Biologie der Thiere, 8, 391-438.

Melle, W. von (1888) Gustav Heinrich Kirchenpauer. Ein Lebens- und Zeitbild. Verlag von Leopold Voss, Hamburg, 459 pp.

Millard, N.A.H. (1975) Monograph on the Hydroida of southern Africa. Annals of the South African Museum, 68, 1-513.

Muller, F. von (1884) A record of localities of some New South Wales zoophytes, as determined by Dr. Kirchenpauer. Proceedings of the Linnean Society of New South Wales, 9, 534-536.

Nutting, C.C. (1900) American hydroids. Part I. The Plumularidae. Smithsonian Institution, United States National Museum Special Bulletin, 4(1), 1-285.

Nutting, C.C. (1904) American hydroids. Part II. The Sertularidae. Smithsonian Institution, United States National Museum Special Bulletin, 4(2), 1-325.

Pagenstecher, H.A. (1885) Die von Dr. G.A. Fischer auf der im Auftrage der Geographischen Gesellschaft in Hamburg unternommenen Reise in das Massai-Land gesammelten Säugethiere. Jahrbuch der Hamburgischen Wissenschaftlichen Anstalten, 2, 29-46.

Pallas, P.S. (1771) Reise durch verschiedene Provinzen des russischen Reichs. Erster Theil. Kayserliche Academie der Wissenschaften, St Petersburg, 504 pp.

Reuss, A.E. (1869) Paläontologische Studien über die Älteren Tertiärschichten der Alpen. II. Abtheilung. Die Fossilen Anthozoen und Bryozoen der Schichtengruppe von Crosara. Denkschriften der Kaiserlichen Akademie der Wissenschaften. Mathematisch-Naturwissenschaftliche Classe, 29(1), 215-298.

Riedl-Lorjé, J.C. \& Gaumert, T. (1982) 100 Jahre Elbe-Forschung. Hydrobiologische Situation und Fischbestand 1842 - 1943 under dem Einfluß von Stromverbau und Sieleinleitungen. Archiv für Hydrobiologie, Supplement 61, 3, 317-378.

Samson, H. von (1890) Gustav Heinrich Kirchenpauer. Ein Lebens- und Charakterbild. Baltische Monatsschrift, 37, 515-603.

Schuchert, P. (2003) Hydroids (Cnidaria, Hydrozoa) of the Danish expedition to the Kei Islands. Steenstrupia, 27, $137-256$.

Schuchert, P. (2004) Revision of the European athecate hydroids and their medusae (Hydrozoa, Cnidaria): families Oceanidae and Pachycordylidae. Revue Suisse de Zoologie, 111, 315-369.

Stechow, E. (1919) Zur Kenntnis der Hydroidenfauna des Mittelmeeres, Amerikas und anderer Gebiete, nebst Angaben über einige Kirchenpauer'sche Typen von Plumulariden. Zoologische Jahrbücher, Abteilung für Systematik, Geographie und Biologie der Tiere, 42, 1-172.

Stechow, E. (1921) Neue Genera und Species von Hydrozoen und anderen Evertebraten. Archiv für Naturgeschichte, Abteilung A. 3. Heft, 87, 248-265.

Studer, T. (1889) Die Forschungsreise S.M.S. “Gazelle” in den Jahren 1874 bis 1876 unter Kommando des Kapitän zur See Freiherrn von Schleinitz herausgegeben von dem Hydrographischen Amt des Reichs-Marine-Amts. III. Theil. Zoologie und Geologie. Ernst Siegfried Mittler \& Sohn, Berlin, 322 pp.

Thompson, d'A.W. (1879) On some new and rare hydroid zoophytes (Sertulariidae and Thuiariidae) from Australia and New Zealand. Annals and Magazine of Natural History, fifth series, 3, 97-114.

Thompson, d'A.W. (1885) A bibliography of Protozoa, sponges, Coelenterata, and worms, including also the Polyzoa, Brachiopoda and Tunicata, for the years 1861-1883. Cambridge University Press, Cambridge, 284 pp.

Wohlwill, A. (1903) Die hamburgischen Bürgermeister Kirchenpauer, Petersen, Versmann. Beiträge zur Deutschen Geschichte des neunzehnten Jahrhunderts. Otto Meissners Verlag, Hamburg, 196 pp. 